\title{
A MAGYARORSZÁGI ERDEI ASZÁLYKÁROK FÉL ÉVSZÁZADOS TRENDJEI (1962-2011)
}

\author{
Hirka Anikó1, Pödör Zoltán², Garamszegi Balázs ${ }^{3}$ és Csóka György' \\ ${ }^{1}$ NAIK Erdészeti Tudományos Intézet, Erdővédelmi Osztály \\ ${ }^{2}$ Soproni Egyetem, Informatikai és Gazdasági Intézet \\ ${ }^{3}$ NAIK Erdészeti Tudományos Intézet, Ökológiai Osztály
}

\begin{abstract}
Kivonat
Az 1962-2011 közötti 50 évben Magyarországon az aszályok gyakorisága nött. A növekvő trenden túl az időszak második felében a kifejezetten extrém aszályok is egyre gyakoribbá váltak. Ezzel szoros összefüggésben jelentősen növekedtek az erdeinkben bekövetkező aszálykárok is. Az évente bejelentett aszálykárok rendkivül szoros, szignifikáns összefüggést mutattak a két vizsgált aszályindex (Pálfai-féle és Forestry Aridity Index) éves értékeivel. Ezek az összefüggések mindkét aszályindex esetében exponenciális jellegüek voltak. A korábbiaktól eltérően az aszálykárok az utóbbi időszakban nemcsak síkvidéki fiatalosokban, hanem hegyvidéki, idősebb, őshonos állományokban is fellépnek. Bizonyított, hogy a kocsánytalan tölgyesek és a bükkösök egészségi állapotában az aszályok döntő szerepet játszanak. A megnövekedett gyakoriságú és mértékü aszályok közvetlen károkozásuk mellett súlyos közvetett hatással is bírnak, ami jellemzően kárláncolatok formájában jelenik meg. Az aszályosság általában pozitívan hat számos rovarfaj tömeges elszaporodására. Az aszálystressz miatt legyengült állományokban tömegesen léphetnek fel, és okozhatnak tömeges fapusztulást olyan kórokozók, amik kedvező időjárású időszakban csak kisebb jelentőséggel bírnak. Amennyiben az aszályok (és egyéb más időjárási extremitások) gyakorisága és súlyossága a jövőben növekedni fog, erdeinkben az eddigieknél is erősebb kárnyomás, és további jelentős egészségi állapot romlás prognosztizálható. Ebböl kiindulva az erdőgazdálkodási/erdőművelési beavatkozások az erdők ellenálló/visszaszerző képességének növelésére kell, hogy irányuljanak. A reaktív erdővédelmi szemléletet a hosszú távú, proaktív megközelitésnek kell felváltania.
\end{abstract}

Kulcsszavak: erdei aszálykár, aszály index, aszálystressz, kárláncolat, növekvő kárnyomás.

\section{YEARS TRENDS OF THE FOREST DROUGHT DAMAGE IN HUNGARY (1962-2011)}

\begin{abstract}
The frequency of droughts increased in Hungary between 1962 and 2011. On top of this increasing trend, the extreme droughts had become more and more frequent. As a response for this, forest drought damage also showed an increasing trend. The yearly values of the forest drought damage showed a significant response for the yearly values of two drought indices (Pálfai and Forest Aridity index). Drought damage is reported not only from younger lowland stands, but also from older native stands of montane regions. It is proven that droughts play a decisive role in the health of sessile oak and beech stands. On top of their direct impacts, droughts have major indirect effects on forest health, manifesting in "damage chains". Droughts regularly have positive effects on outbreaks of many forest insects. The trees and stands weakened by drought stress can successfully be attacked by pathogens which are less aggressive amid better weather conditions. If the frequency and severity of droughts (and other weather extremes) increase (as it is predicted), our forests will suffer from an even higher damage pressure, so further negative health trends can be predicted in Hungarian forests. Therefore the forest management/sylviculture should aim at increasing forest resistance/resilience. The reactive forest protection should be changed for a long term proactive approach.
\end{abstract}

Keywords: forest drought damage, drought indices, drought stress, damage chain, increasing damage pressure. 


\section{BEVEZETÉS}

A klímaváltozás környezetünk szinte minden élettelen és élő elemére, így erdeinkre is jelentős hatással van. Leginkább azok az erdőterületek érintettek, ahol az adott terület fafaja(i) az elterjedésének szárazsági határán helyezkedik el (Mátyás et al. 2010). A klímaváltozás egyik legmeghatározóbb eleme az aszályos időjárási periódusok gyakoriságának és hosszának növekedése (Carnicer et al. 2011, Hlásny et al. 2014, Bendixsen et al. 2015, Assal et al. 2016, Hubbart et al. 2016). A mezőgazdasági és az erdei aszálykárok témája régóta foglalkoztatja mind a gyakorlati szakembereket, mind pedig a kutatókat (Bús 1995, Csóka et al. 2007, 2009, Hirka és Csóka 2010, Mátyás et al. 2010). Az aszálykár leggyakoribb közvetlen és jól érzékelhető hatása a lombozat idő előtti lehullása (Bréda et al. 2006), ill. a fák növedékcsökkenése (Führer 1995, Lindner et al. 2014). Súlyosabb esetben, több éven át tartó aszály esetén egyes fák, ill. állományok pusztulása is bekövetkezhet (Thomas et al. 2002, Suarez et al. 2004, Allen et al. 2010, Poulos 2014, Schwantes et al. 2016).

A fentiekből kiindulva az erdei aszálykárok jövőben várható mértékének előrejelzése (amire elsősorban a meglévő hosszú távú, visszamenőleges adatsorok biztositanak lehetőséget), a várható károk mértékének lehetőség szerinti meghatározása nagy jelentőséggel bír az erdőgazdálkodás hosszú távú tervezése, illetve a károk kockázatának mérséklése szempontjából.

\section{ANYAG ÉS MÓDSZER}

Az éves aszálykárok idősorának értékelése előtt magát a kiváltó meteorológiai-éghajlati hátteret is vizsgáltuk Magyarország térségére, a Pálfai-féle aszályindex, PAI (Pálfai 2002) és a Forestry Aridity Index, FAl (Führer et al. 2011) segítségével. A későbbiekben bemutatott Pettitt-féle töréspont-elemzéssel (Sneyers 1992; Mares \& Mares, 1994) igyekeztünk a klimatikus adatokat a károk intenzitásában kimutatható változásokkal ok-okozati viszonyba hozni. Az elmúlt évtizedek aszályperiódusainak területi változékonyságát is összehasonlítottuk két kivágat példáján. Az intenzívebb aszálykárok területi fellépéséhez igazodva az Északi-középhelység (ÉKHG) és a Nyugat-Dunántúl (NYDT) regionális idősorát képeztük, melyek rendre az É.sz. $47,75^{\circ}-48,50^{\circ}$, K.h. $19,00^{\circ}-21,50^{\circ}$, illetve az É.sz. $46,00^{\circ}-$ $47,25^{\circ}$, K.h. $17,00^{\circ}-18,50^{\circ}$ földrajzi szélességi és hosszúsági körök által határolt területek átlagát jelentik a CARPATCLIM projekt (Szalai et al. 2013) 1961-2010. időszakra elérhető rácshálós éghajlati adatainak felhasználásával.

A meteorológiai-éghajlati háttér vizsgálata után elvégeztük az aszálykárok idősorának értékelését is. Az 1960-as évek elejétől 2011-ig az erdőgazdálkodók évente 4 alkalommal kötelesek voltak az ún. „Erdővédelmi Jelzőlapok” kitöltésével adatokat szolgáltatni az erdeikben előforduló károkról, ezen belül az aszálykárok kiterjedéséröl is. 2012-től kezdve az adatgyüjtés módszere némileg változott, ezért ennek az első 50 évnek az adatait használ- 
tuk fel az elemzésekhez. Az éves aszálykárokat a Kormányhivatalok 10 Erdészeti Igazgatóságának illetékességi területe szerint csoportosítottuk (1. ábra).

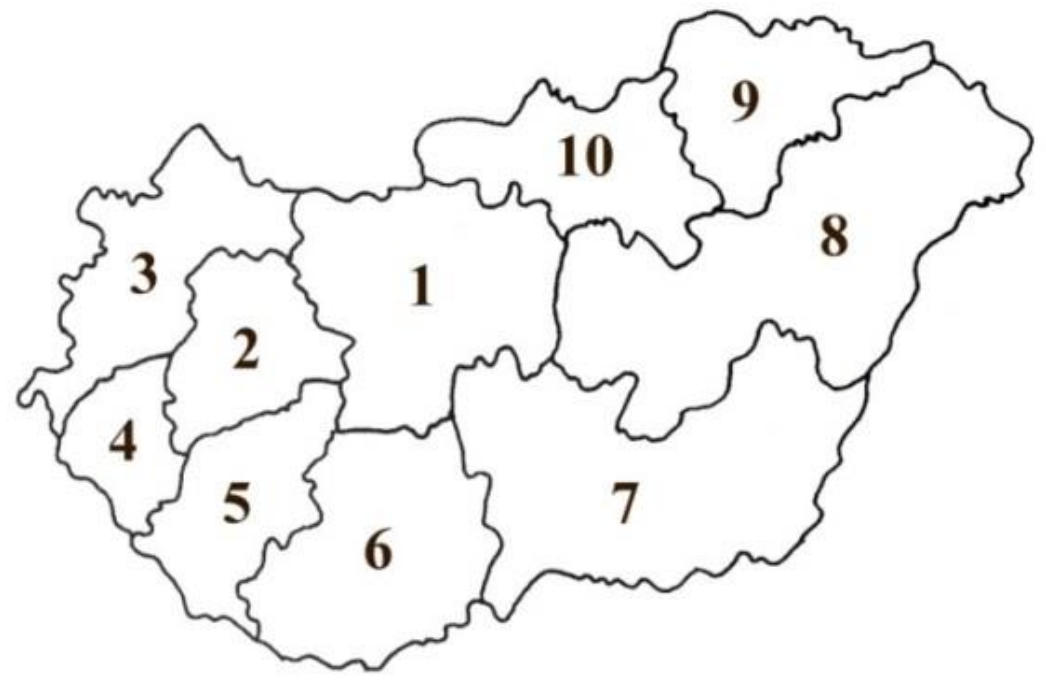

1. ábra: A KH Erdészeti lgazgatóságainak illetékességi területei. Figure 1: Regions of the Forestry Directorates.

Az aszálykárokat évenként összegeztük, az évenkénti értékeket összevetettük a Pálfaiféle aszályindex-szel (Pálfai 2002), illetve a FAl-val (Führer et al. 2011).

Az 1962-2011-es időszakot két egyenlő részre osztva (1962-1986, illetve 1987-2011), ábrázoltuk a bejelentett károk nagyságát, Erdészeti Igazgatóságok szerinti bontásban.

Töréspont elemzést alkalmaztunk az idősorokban kimutatható jelentős változások detektálására. A vizsgálatok során a cél az volt, hogy objektív módon felosszuk az idősort két részre úgy, hogy a részek adatsorai között statisztikailag igazolható, szignifikáns különbség legyen. A töréspont az idősor azon pontja (pontjai), amikor ez az eltérés a két részidöszak között maximális és statisztikailag kimutatható.

A szakirodalom több módszert is ismer töréspontok kimutatására, mint például a részidőszakok átlagértékeinek összehasonlításán alapuló Student-féle t-teszt, a Wilcoxon teszt, vagy a Pettitt-féle nemparaméteres megközelítés (Sneyers 1992; Mares \& Mares, 1994). Figyelembe véve, hogy adatsoraink nem minden esetben normális eloszlásúak nemparaméteres próbákat alkalmaztunk. Elemzésünkben a változások kimutatására a Pettitt-féle töréspont vizsgálatot alkalmaztuk. Ez a nemparaméteres próba a Mann-Whitney teszten alapulva hasonlít össze két mintát. A lehetséges töréspont előtti és mögötti időszakok adatainak eloszlásait összehasonlítva keresi a statisztikailag szignifikáns eltérést adó töréspontokat. A töréspont vizsgálatokat elvégeztük a Student-féle t-teszten alapuló megközelités nemparaméteres változatával, a Wilcoxon teszttel is. 


\section{EREDMÉNYEK}

Az alkalmazott statisztikai próba segítségével definiálható töréspontokat és az így meghatározott részidősorok néhány statisztikai jellemzőjét az 1. táblázat tartalmazza. Magukat a klímaadatokat grafikonon is ábrázoltuk az 1961-2010 közötti időszakra (2-3. ábra), lehetőséget adva egyben a PAl és FAI indexek közötti, illetve a PAI esetén az említett regionális különbségek jobb áttekintésére is.

A táblázatban közölt adatok és a grafikonok is az aszályesemények gyakoriságának és erélyének növekedését mutatják az 1980-as évek elejétől kezdődően. A grafikonok egyben a PAl és FAl indexek jó együttfutását is szemléltetik. Ennek ellenére, a FAl adatok esetén a szignifikáns töréspontok hiánya, láthatóan az erre az indexre jellemző 1976 és 1983 közötti „fokozatosabb átmenetnek” köszönhető (2. ábra). A regionális különbségek elsösorban az 1990-es évek eleji (Északi-középhegység) és a 2003-as (Dunántúl) aszályok intenzitásában figyelhetőek meg (3. ábra). A grafikonokról szintén látható, hogy a Pettittteszt segítségével kimutatott töréspontok nem csupán a görbék magasabb átlagértékek irányába történő elmozdulását, de sokkal inkább az éves aszályértékek száraz extrém értékek irányába történő aszimmetrikus eltolódását jelentik (4. ábra).

1. táblázat: Az aszályindexek (Pálfai-féle - PAl és Forest Aridity Index - FAl) idősoraiban Pettitt-teszt segítségével azonositott töréspontok és az így definiált részidősorok $\left(P_{1}, P_{2}\right)$ néhány statisztikai jellemzője Magyarország területére (HUN) és két regionális kivágatra (Északi-középhegység - ÉKHG és Nyugat-Dunántúl - NYDT). A vastag szedés szignifikáns változásokat jelöl $(p<0,05)$.

Table 1: Breakpoints defined with the Pettitt test in the time series of the Aridity Indices (PAI - Pálfai; FAlForest Aridity Index) and certain statistical characteristics of the time periods defined from these $\left(P_{1}, P_{2}\right)$ for the territory of Hungary (HUN) and two regional guadrangles (Mountains of Medium Height (ÉKHG) and Western Transdanubia (NYDT)). Bold text indicates significant changes $(p<0,05)$.

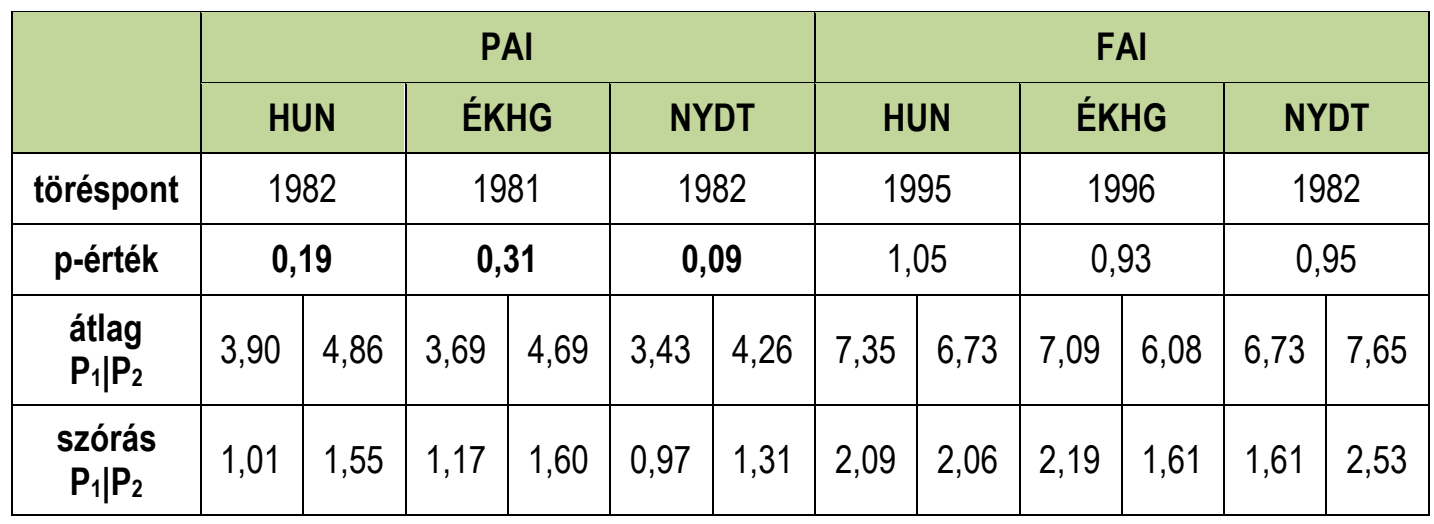




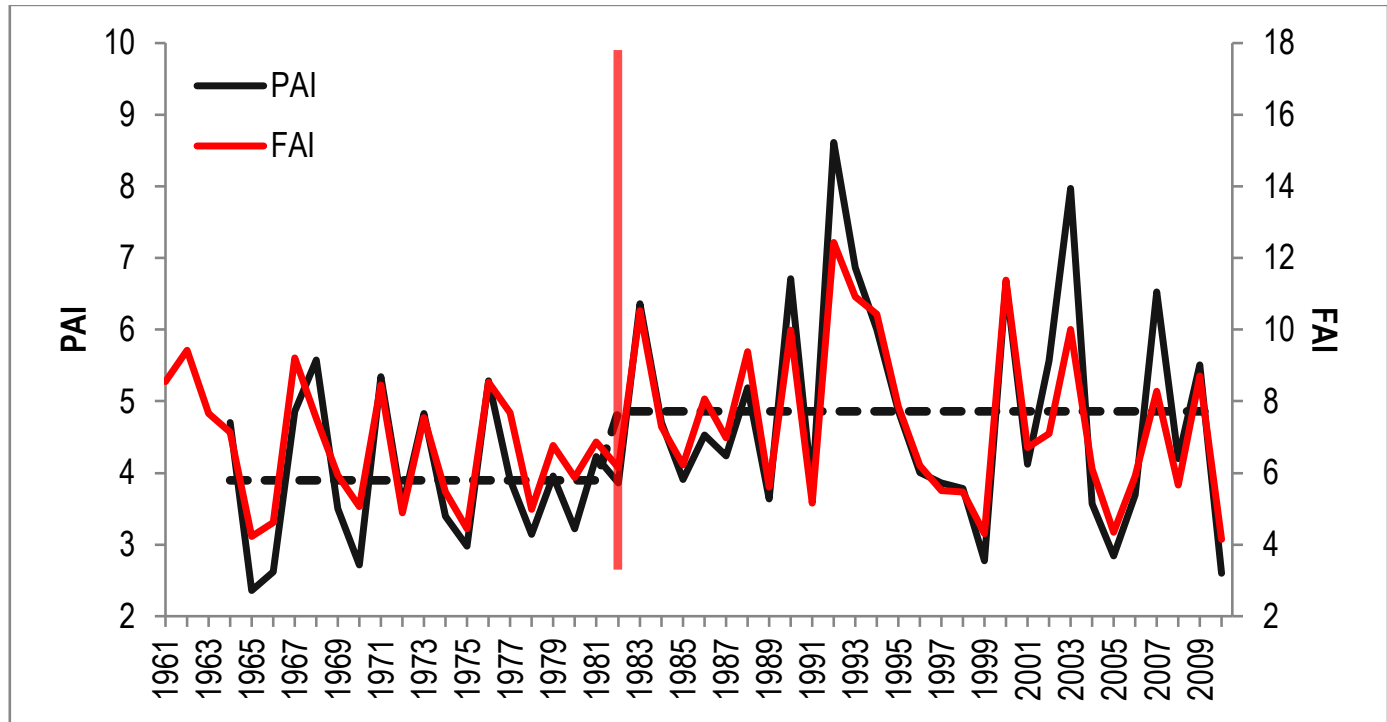

2. ábra: A Pálfai (PAl) és a Forest Aridity Index (FAl) magyarországi átlagos idősorai 1961 és 2010 között, a töréspont által meghatározott részidőszakok PAl átlagaival. (Adatok forrása: CARPATCLIM.)

Figure 2: Time series of the yearly averages of the Pálfai and the Forest Aridity Indices between 1962 and 2010 with the averages of PAI for the two periods defined with the breakpoint analysis.

(Source of data: CARPATCLIM.)

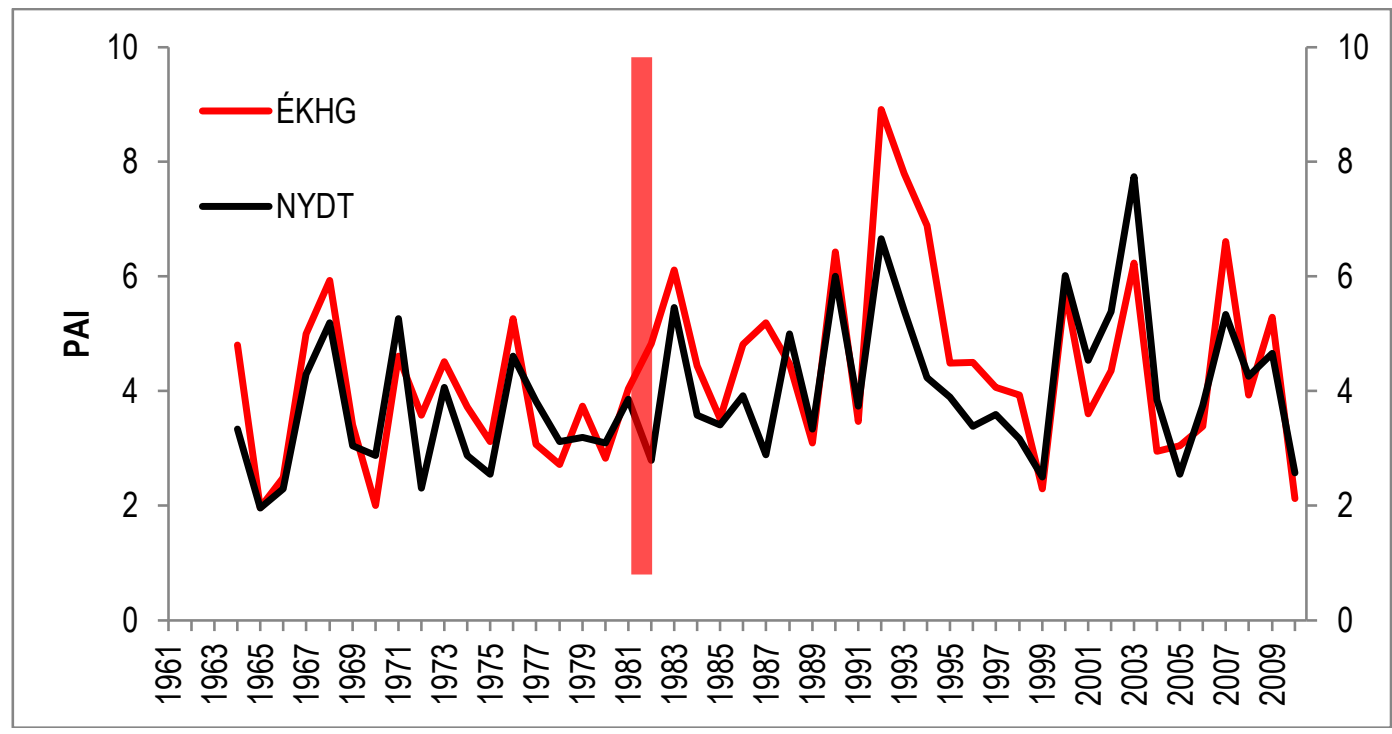

3. ábra: A Pálfai-féle aszályindex (PAl) idősorai 1961 és 2010 között az Északi-középhegység (ÉKHG) és a Nyugat-Dunántúl (NYDT) térségére. (Adatok forrása: CARPATCLIM.)

Figure 3: Time series of the Pálfai Aridity Index between 1961 and 2010 for the Northern Mountains of Medium Height (ÉKHG) and for Western Transdanubia (NYDT). (Source of data: CARPATCLIM.) 


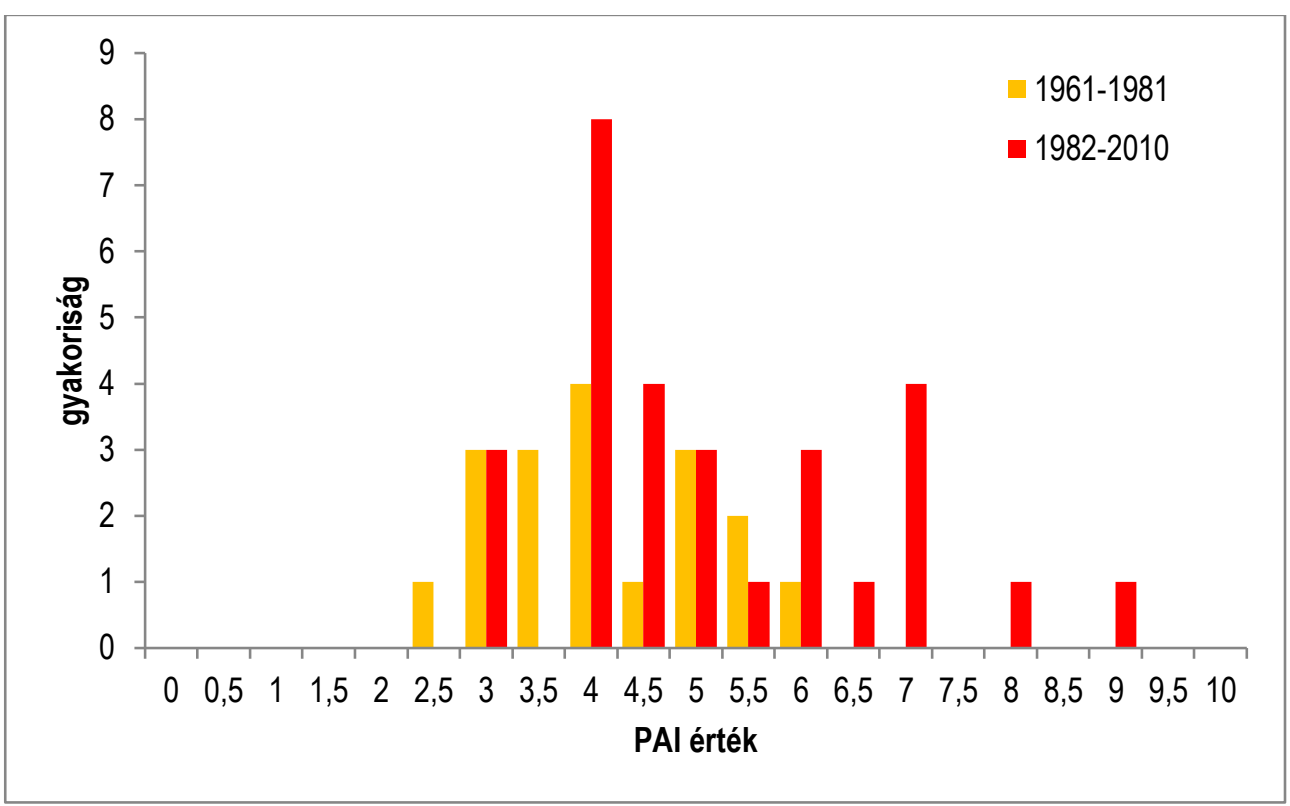

4. ábra: A Pálfai-féle aszályindex (PAl) országos átlagértékeinek eloszlása a töréspont-elemzés által meghatározott 1961-1981 és 1982-2010 időszakokra.

Figure 4: Frequency distribution of the yearly average values of the Pálfai Drought Index for two time periods (1961-1981 and 1982-210) defined by the breakpoint analysis.

A magyarországi erdőkárok a '60-as évektöl napjainkig növekvő tendenciát mutatnak, ezen belül a biotikus és abiotikus károk is növekednek (Hirka et al. 2009).

A jelentett károk esetében az aszálykárok alatt erdei fáknál az idő előtt bekövetkező lombszáradást, lombhullást értjük, amely más biotikus okokra közvetlenül nem vezethető vissza. Az aszály hatása általában ritkán vezet közvetlenül az adott évben a faegyed elpusztulásához, de gyengíti a fák ellenálló képességét, melynek következtében egyes rovarok és kórokozók károkozása felerősödhet. Az adott évben történő fapusztulás (kiszáradás) általában a fiatalabb faegyedek esetében jellemző. Emellett jelentős növedékveszteség is kialakulhat (Führer 1995).

Az 1962-2011-es időszakban az aszálykárok évente eltérő mértékben, éves átlagban 6269 ha-on sújtották a magyar erdőket (5. ábra). Egyes években nincs, vagy alig érzékelhető a kár, míg más években több 10 ezer ha-ról is jelentik. Ez az abiotikus kárforma jelentkezett eddig legnagyobb területen erdeinkben, 1993-ban, több mint 45 ezer ha-on. Az időszak második felében egy emelkedő tendencia figyelhető meg. Az évek közötti jelentős változatosság egyébként más országokban, így pl. Finnországban is jellemző (Muukonen et al. 2015). 


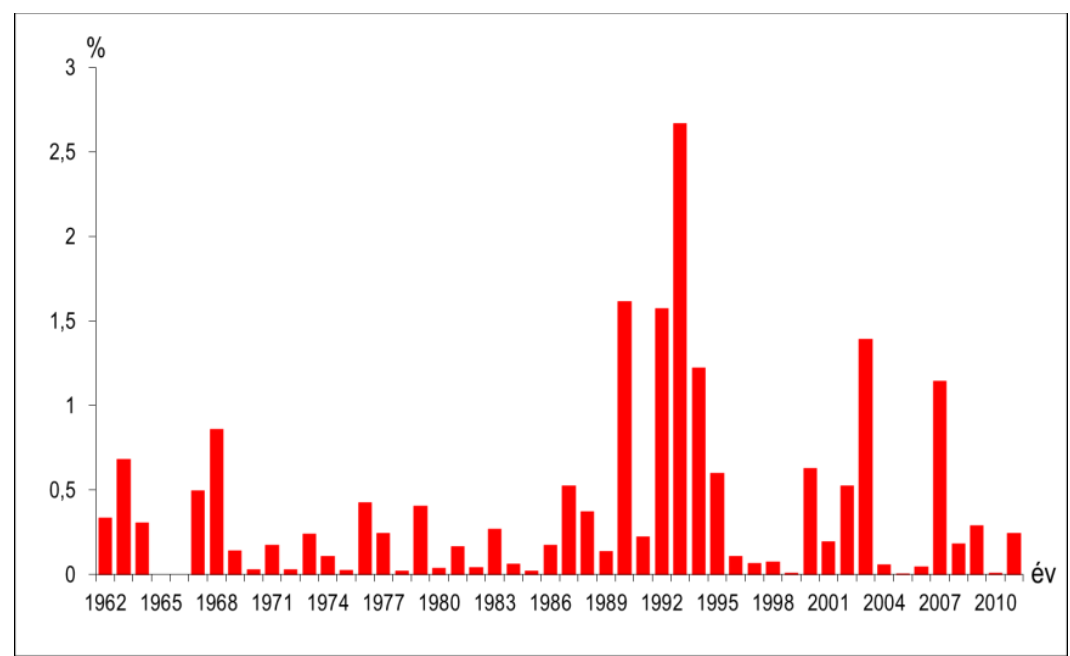

5. ábra: Éves összesitett aszálykárok Magyarországon az erdőterület arányában 1962 és 2011 között.

(Adatok forrása: Erdészeti Tudományos Intézet erdőkár adatbázis.)

Figure 5: Forest drought damage in the Hungarian Forests between 1962 and 2011 in percentage of the actual forest land. (Source of data: forest damage database of the Forest Research Institute.)

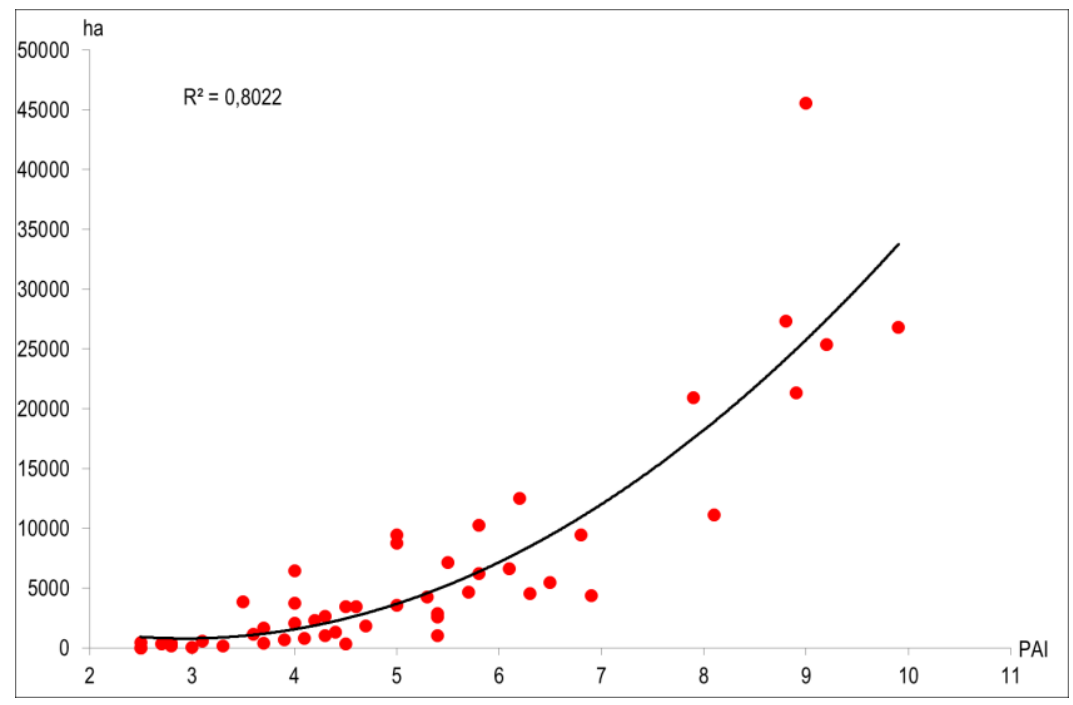

6. ábra: Összefüggés a Pálfai-féle aszályindex és az erdei aszálykárok között. (Adatok forrása: Erdészeti Tudományos Intézet erdőkár adatbázis; Dr. Pálfai Imre.)

Figure 6: Correlation of the Pálfai Aridity Index and the yearly forest drought damage. (Source of data: forest damage database of the Forest Research Institute; Dr. Imre Pálfai.)

Az éves káradatok összevetése a PAl-val, ill. a FAl-val, mindkét esetben szoros, szignifikáns összefüggést adott $\left(R^{2}=0,80\right.$, ill. $\left.R^{2}=0,56\right) p<0,001$ szinten (6., 7. ábra). Aszályos években tehát a jelentett aszálykárok nagysága is magas, sőt az is megfigyelhető, hogy ha 
egymást követik az aszályos évek (pl. 1992-1993-ban), akkor kiugróan magas aszálykárok alakulhatnak ki. Megjegyzendő továbbá, hogy ezek az összefüggések exponenciális jellegüek.

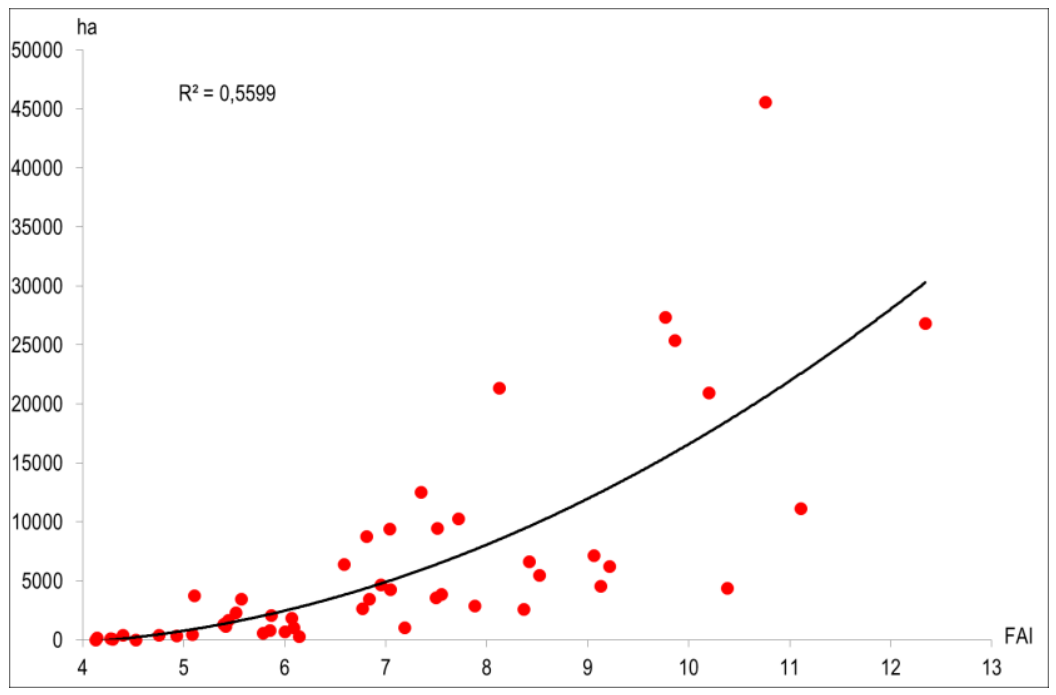

7. ábra: Összefüggés a Forest Aridity Index és az erdei aszálykárok között.

(Adatok forrása: Erdészeti Tudományos Intézet erdőkár adatbázis; Dr. Führer Ernő.)

Figure 7: Correlation of the Forest Aridity Index and the yearly forest drought damage. (Source of data: forest damage database of the Forest Research Institute; Dr. Ernő Führer.)

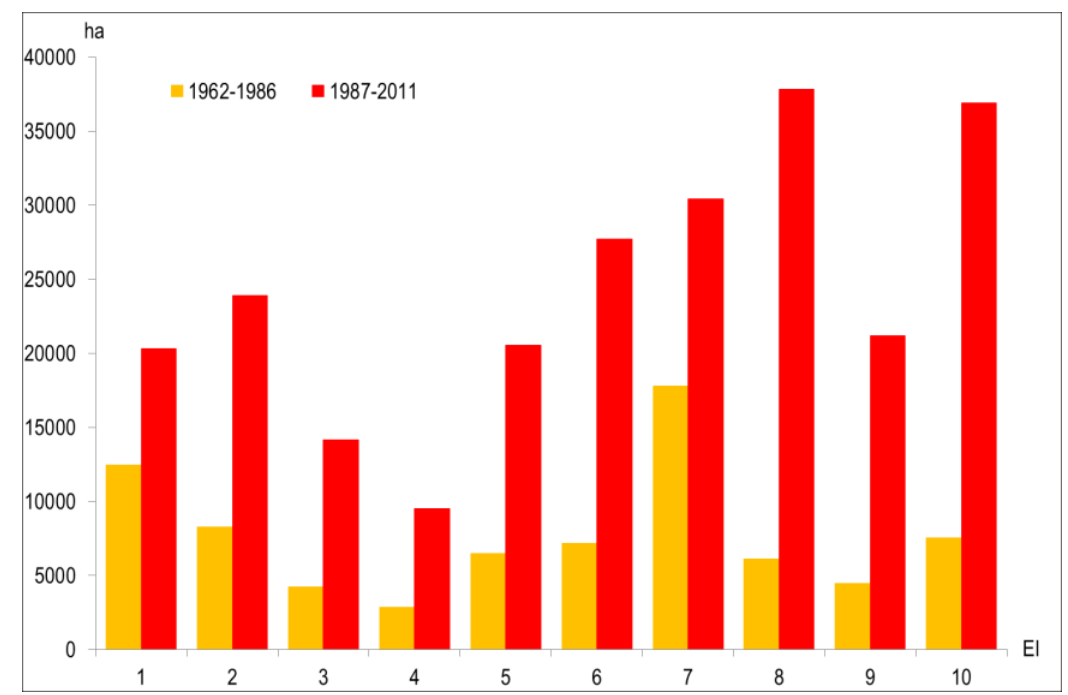

8. ábra: Erdei aszálykárok Magyarországon az 1962-1986 és az 1987-2011-es időszakokban a KH Erdészeti Igazgatóságai szerint. (Adatok forrása: Erdészeti Tudományos Intézet erdőkár adatbázis.)

Figure 8: Average values of forest drought damage for two periods (1962-1986; 1987-2011) by Forestry Directorates. (Source of data: forest damage database of the Forest Research Institute.) 
Az aszálykárok területi megoszlása változatos képet mutat (8. ábra). Egyes Erdészeti Igazgatóságok (EI) területén az aszálykárok az 1962-2011-es időszakban kisebb mértékben emelkedtek (pl. 1, $7 \mathrm{El}$ ), míg másokban (pl. 5, $10 \mathrm{EI}$ ) eröteljes növekedés volt megfigyelhető. Amennyiben az időszakot két egyenlő részre osztjuk, megfigyelhető, hogy különbségek vannak a két időszakban az egyes El-k esetében. Mindegyik El esetében megállapitható, hogy az utóbbi 25 év aszálykárai meghaladták az előző 25 év aszálykárait. A legjelentősebb növekedés a 8-as és 10-es El esetében figyelhető meg. A legnagyobb arányú növekedés nem az alföldi „klasszikus” aszályos területeken, mint pl. a Duna-Tisza közén volt, hanem a hegyvidéki területeken (pl. Mátra, Cserhát, Börzsöny).

Az egyes részidőszakok közötti jelentős különbségek statisztikai elemzésére a Pettittféle töréspont vizsgálatot alkalmaztuk. A töréspont elemzéséhez 50 éves adatsorok álltak rendelkezésre 10 helyröl, amikböl országosan egyesitett adatsort is képeztünk.

A kapott eredmények azt mutatják (2. táblázat), hogy a 1, 3 és 7-es régiók kivételével az ország jelentős részén $(2,4,5,6,8,9,10$ El területek), beleértve az országos átlagot is, szignifikáns növekedés adódott. A legszorosabb összefüggést mutató terület, ill. az összesített adatsor idősor adatait grafikonon is ábrázoltuk (9., 10. ábra). A töréspont vizsgálatokat elvégeztük a Student-féle t-teszten alapuló megközelítés nemparaméteres változatával, a Wilcoxon teszttel is. A két megközelítés ugyanazt az eredményt hozta.

2. táblázat: Pettitt-teszt eredményei (TP=töréspont, El=Erdészeti Igazgatóság, átlag1, átlag2: a töréspont elötti és az azt követő időszak átlaga). A szignifikáns értékek vastagon szedve.

Table 2: Resuts of the Pettitt breakpoint analysis (TP= breakpoint; EK=Forestry Directorate; „átlag1" and „átlag2" averages of the periods before and after the breakpoint). The significant values are given in bold.

\begin{tabular}{|c|c|c|c|c|c|c|c|c|c|c|c|}
\hline EI & $\mathbf{1}$ & $\mathbf{2}$ & $\mathbf{3}$ & $\mathbf{4}$ & $\mathbf{5}$ & $\mathbf{6}$ & $\mathbf{7}$ & $\mathbf{8}$ & $\mathbf{9}$ & $\mathbf{1 0}$ & $\mathbf{1 - 1 0}$ \\
\hline TP (év) & 1995 & 1989 & 1989 & 1989 & 1987 & 1985 & 1995 & 1985 & 1988 & 1989 & 1986 \\
\hline p-érték & 0,95 & $\mathbf{0 , 1 5}$ & 0,53 & $\mathbf{0 , 3 2}$ & $\mathbf{0 , 0 3}$ & $\mathbf{0 , 3 3}$ & 1,03 & $\mathbf{0 , 1 5}$ & $\mathbf{0 , 1 3}$ & $\mathbf{0 , 1 1}$ & $\mathbf{0 , 3 6}$ \\
\hline átlag1 & 454,9 & 207,0 & 104,1 & 68,2 & 164,5 & 192,7 & 627,5 & 156,9 & 114,3 & 182,2 & 2075,8 \\
\hline átlag2 & 277,8 & 609,4 & 364,5 & 246,0 & 481,9 & 620,3 & 496,6 & 847,0 & 532,7 & 957,2 & 5545,4 \\
\hline különbség & $-177,1$ & 402,4 & 260,4 & 177,8 & 317,5 & 427,6 & $-130,9$ & 690,1 & 418,5 & 775,0 & 3469,6 \\
\hline
\end{tabular}




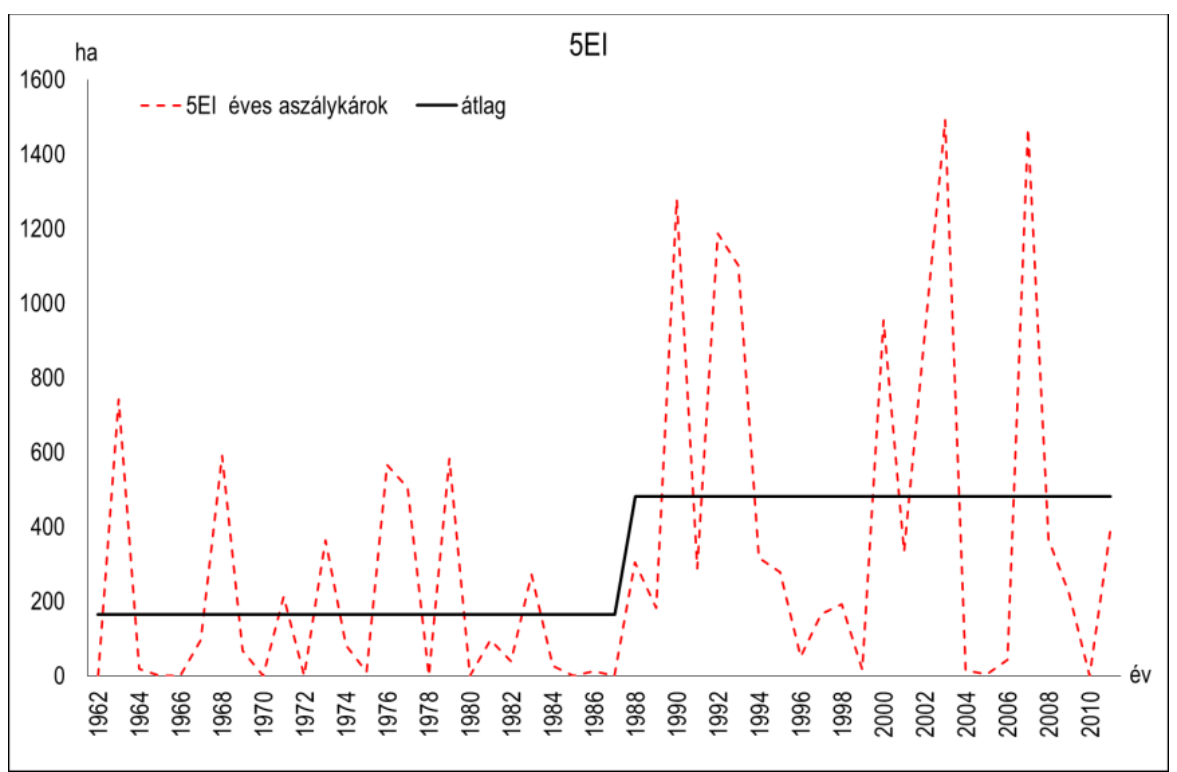

9. ábra: Pettitt-féle töréspont elemzés eredménye az 5El aszálykár adatainak felhasználásával. (Adatok forrása: Erdészeti Tudományos Intézet erdőkár adatbázis.)

Figure 9: Results of the Pettitt breakpoint analysis for Forestry Directorate 5. (Source of data: forest damage database of the Forest Research Institute.)

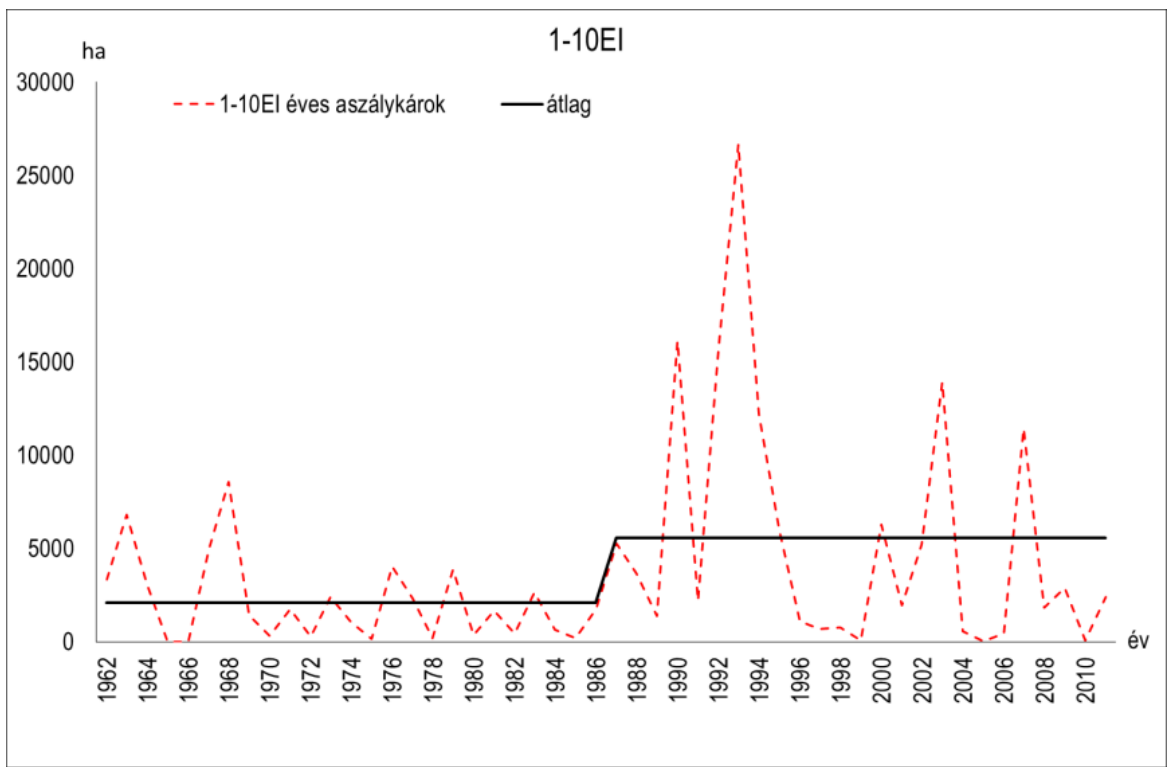

10. ábra: Pettitt-féle töréspont elemzés eredménye az 1-10El aszálykár adatainak felhasználásával. (Adatok forrása: Erdészeti Tudományos Intézet erdőkár adatbázis.)

Figure 10: Results of the Pettitt breakpoint analysis for Forestry Directorate 1-10.

(Source of data: forest damage database of the Forest Research Institute.) 


\section{MEGVITATÁS}

Magyarországon az utóbbi, mintegy 3 évtizedben jelentősen növekedett az aszályok gyakorisága és súlyossága. Nem meglepő módon, ezzel szoros összefüggésben drasztikusan növekedett az erdei aszálykárok mértéke is. Külön is megjegyzendö, hogy az éves aszálykárok nagysága mindkét aszályindex-szel (PAl és FAl) közel exponenciális összefüggést mutat. Továbbá az is, hogy az erdei aszálykárok az utóbbi időkben már egyáltalán nem korlátozódnak a síkvidéki mesterséges erdőfelújitásokra, ahogyan az korábban jellemző volt, hanem akár hegyvidéki őshonos fafajú állományainkban is jelentősek lehetnek. Hazai tanulmányok is bizonyítják, hogy a kocsánytalan tölgyesek és a bükkösök egészségi állapotát az időjárási viszonyok (nevezetesen az aszályos időszakok) alapvetően befolyásolják (Csóka et al. 2007; Janik et al. 2016).

A tíz régióból hétben szignifikáns, egyben pedig nem szignifikáns növekedést mutatkozott (2. táblázat). Két régióban $(1,7)$ mutatkozott nem szignifikáns csökkenés a töréspontok által meghatározott első és második időszak átlaga között. Ez a tény (még ha a két régióban a csökkenés nem is volt szignifikáns) felhívja figyelmet a régiónkénti változatosság jelentőségére.

Sajnos a teljes vizsgált időszakra vonatkozóan nem volt lehetőségünk finomabb felbontásban vizsgálni azt, hogy az erdei aszálykárok milyen fafajú és korú állományban jelentkeztek. Ennek ismerete azért lehetne hasznos, mert pl. a FAl kifejezetten a folyónövedék kulminációja utáni korosztályokban, a fö növekedési szakaszra épít, így az idősebb állományok éven belüli fő szervesanyag-képzési időszakára érzékeny. A PAl ezzel szemben egy tágabb időszak változóiból képzett index, így a fiatalabb állományokban bekövetkező aszálykároknak jobb prediktora lehet. A két aszályindex összehasonlításánál ezeket a szempontokat mindenkor figyelembe kell venni, azzal együtt is, hogy az összesitett erdei aszálykárokat mindkét index rendkívül nagy mértékben magyarázza. Mivel a magyar erdők túlnyomó része többlet vízhatástól független termőhelyen tenyészik (azaz vízháztartásában a helyi csapadékra utalt) a növekvő mértékü aszályosság növekedésükre és egészségi állapotukra is jelentős negatív hatást gyakorol. A közvetlenül, az adott évben kiváltott fapusztulás elsősorban a fiatalabb állományokra (különösen az erdősítésekre) jellemző, de a hosszabb távon jelentkező közvetett hatások idősebb állományokat is sújthatnak. Az aszálynak az erdöben - a közvetlen hatások mellett - számos egyéb hatása is ismert, többek között meghatározó szerepe van az erdei rovarok népességének, és így az általuk okozott károk alakulásában (Mattson \& Haack 1987; Leskó et al. 1994; Szentkirályi et al. 1994, 1997 Csóka \& Leskó 1995; Csóka 1996, 1997ab, Klapwijk et al. 2013, Kolb et al. 2016). A teljesség igénye nélkül hazai példa erre a zöld karcsúdíszbogár (Agrilus viridis) 2000-es évek elején, Zalában kialakult, korábban nem tapasztalt tömegszaporodása (Lakatos \& Molnár 2009; Molnár et al. 2010), vagy akár a gyapjaslepke kártételeinek vertikális kiterjedése, ill. tömeges fellépése bükkösökben a 2000-es évek közepén (Csóka \& Hirka 2009; Csóka et al. 2015). További példaként említhető, hogy az Európában area-expanziót mutató tölgy búcsújáró lepke népességének fluktuációiban is az aszályosság meghatáro- 
zó, pozitív szerepet játszik (Csóka et al. 2018). Az aszályos időjárás elősegítheti idegenhonos rovarfajok megtelepedését és terjedését (Csóka et al. 2012, Csóka \& Hirka 2011), de egyes nem őshonos kórokozók (pl. Chalara fraxinea) tömeges fellépését és jelentős károkozását is. Ugyanakkor egyes, korábbról is ismert kórokozók jelentősége is megnövekedhet az aszályos időjárás következtében, mint pl. a Biscogniauxia mediterranea (Jurc \& Ogris 2006, Vettraino et al. 2002) és a Cenangium ferruginosum esetében (Jurc et al. 2000, Kunca \& Leontovic 2013), ill. pusztulási folyamatot generálhat lombos- és fenyőállományokban egyaránt (Koltay 1995, 2002, Pernek et al. 2012).

Ismételten megjegyzendő, hogy általában nem az aszályosság önmagában okoz jelentős fapusztulást (kivéve a fiatal állományokat), hanem az aszálystressz miatt legyengült faegyedeken/állományokban fellépő kárláncolatok, amelyekben fafajtól, helytől, időtől függően más-más közremüködő fajok játszhatnak jelentős szerepet. Okkal feltételezhető, hogy a gyakoribbá és súlyosabbá váló aszályok miatt egyre gyakoribbá fognak válni ezek a kárláncolatok is, ami az erdők egészségi állapotának jelentős romlásához, tömeges fapusztuláshoz is vezethet. Ezt támasztja alá az a tény is, hogy vizsgált időszakban nemcsak az aszálykárok (illetve más abiotikus erdőkárok), hanem a biotikus erdőkárok területe is növekedett.

Amennyiben a jövőben a klímaváltozás következtében számítani lehet fokozódó aszályos időjárásra (Gálos et al. 2007), akkor az aszálykárok további, kimagasló növekedése is várható. A más időjárási extrém szituációk (kései fagyok, viharok, ónos, eső, stb.) gyakoriságának növekedése várhatóan még tovább súlyosbítja a helyzetet. Ennek megfelelön a kárkockázatok csökkentésére, valamint az ellenálló-, illetve visszaszerzö-képesség javítására irányuló erdőgazdálkodásnak, erdőmüvelésnek az eddigieknél sokkal nagyobb teret kell kapnia. A reaktív (a kialakult helyzetre rövidtávon reagáló) erdőművelés/erdővédelem helyett a proaktív (hosszú távú megelőző) szemlélet elfogadása és gyakorlása teljességgel elkerülhetetlennek látszik.

\section{KÖSZÖNETNYILVÁNÍTÁS}

Az aszálykárokkal kapcsolatos kutatómunkánkat a VKSZ_12-1-2013-0034-Agrárklíma.2 projekt támogatásával végeztük. Köszönettel tartozunk Dr. Pálfai Imrének és Dr. Führer Ernőnek, akik rendelkezésünkre bocsátották az általuk kifejlesztett aszályindexek adatsorait.

\section{FELHASZNÁLT IRODALOM}

Allen C.D., Macalady A.K., Chenchouni H., Bachelet D., McDowell N., Vennetier M., et al. 2010: A global overview of drought and heat-induced tree mortality reveals emerging climate change risks for forests. Forest Ecology and Management 259: 660-684. DOI: 10.1016/j.foreco.2009.09.001 
Assal T.J., Anderson P.J. \& Sibold J. 2016: Spatial and temporal trends of drought effects in a heterogeneous semi-arid forest ecosystem. Forest Ecology and Management 365: 137-151. DOI: 10.1016/j.foreco.2016.01.017

Bendixsen D.P., Hallgren S.W. \& Frazier A.E. 2015: Stress factors associated with forest decline in xeric oak forests of south-central United States. Forest Ecology and Management 347: 40-48. DOI: 10.1016/j.foreco.2015.03.015

Bréda N., Huc R., Granier A. \& Dreyer E. 2006: Temperate forest trees and stands under severe drought: a review of ecophysiological responses, adaptation processes and long-term consequences. Annals of Forest Science 63: 625-644. DOI: 10.1051/forest:2006042

Bús M. 1995: Az erdei aszálykár és a fafajok szárazságtürésének vizsgálata a Bakonyban és a Balatonfelvidéken. In: Tar K., Berki I. \& Kiss Gy. (eds): Erdő és klíma I. kötet, Noszvaj, 209-216.

Carnicer J., Coll M., Ninyerola M., Pons X., Sánchez G. \& Penuelas J. 2011: Widespread crown condition decline, food web disruption, and amplified tree mortality with increased climate change-type drought. Proceedings of the National Academy of Sciences 1-5. DOI: 10.1073/pnas.1010070108

Csóka Gy. 1996: Aszályos évek-fokozódó rovarkárok erdeinkben. Növényvédelem 32(11): 545-551.

Csóka Gy. 1997a: Aszályosság és az erdei rovarkárok. In: Tar K. \& Szilágyi K. (eds): Erdő és Klíma II. kötet, Sopron, 90-93.

Csóka Gy. 1997b: Increased insect damage in Hungarian forests under drought impact. Biologia 52(2): 1-4.

Csóka Gy. \& Hirka A. 2009: A gyapjaslepke (Lymantria dispar L.) legutóbbi tömegszaporodása Magyarországon. Növényvédelem 45(4): 196-201.

Csóka Gy. \& Hirka A. 2011: Alien and invasive forest insects in Hungary (a review). In: Delb H. \& Pontuali S. (eds): Biotic Risks and Climate Change in Forests, Proceedings of the 10th IUFRO Workshop of WP 7.03.10 „Methodology of Forest Insect and Disease Survey in Central Europe”, September 20-23, 2010, Freiburg, Germany, 54-60.

Csóka Gy., Hirka A. \& Szőcs L. 2012: Rovarglobalizáció a magyar erdőkben. Erdészettudományi közlemények 2(1): 187-198.

Csóka Gy., Hirka A., Szőcs L., Móricz N., Rasztovits E. \& Pödör Z. 2018: Weather-dependent fluctuations in the abundance of the oak processionary moth, Thaumetopoea processionea (Lepidoptera: Notodontidae). European Journal of Entomology 115: 249-255. DOI: 10.14411/eje.2018.024

Csóka Gy., Koltay A., Hirka A. \& Janik G. 2007: Az aszályosság hatása kocsánytalan tölgyeseink és bükköseink egészségi állapotára. In: Mátyás Cs. \& Vig P. (eds): Erdő és klíma V. kötet, Sopron, 229-239.

Csóka Gy., Koltay A., Hirka A. \& Janik G. 2009: Az aszályosság hatása kocsánytalan tölgyesek és bükkösök egészségi állapotára. Klíma-21 Füzetek 57: 64-73.

Csóka Gy. \& Leskó K. 1995: Klimatikus anomáliákat indikáló erdei rovarok. In: Tar K., Berki I. \& Kiss Gy. (eds): Erdő és klíma I. kötet, Noszvaj, 163-170.

Csóka Gy., Pödör Z., Nagy Gy. \& Hirka A. 2015: Canopy recovery of pedunculate oak, Turkey oak and beech trees after severe defoliation by gypsy moth (Lymantria dispar): Case study from Western Hungary. Forestry Journal (Lesnicki Casopis) 61: 143-148. DOI: 10.1515/forj-2015-0022

Führer E. 1995: Az időjárás változásának hatása az erdő fatermő képességére és egészségi állapotára. Erdészeti Lapok 130(6): 176-178.

Führer E., Horváth L., Jagodics A., Machon A. \& Szabados I. 2011: Application of a new aridity index in Hungarian forestry practice. Időjárás 115(3): 205-2016.

Gálos B., Lorenz Ph. \& Jacob D. 2007: Will dry events occur more often in Hungary in the future? Environmental Research Letters 2(3): 034006. DOI: 10.1088/1748-9326/2/3/034006

Hirka A. \& Csóka Gy. 2010: Abiotikus károk Magyarország erdeiben. Növényvédelem 46(11): 513-517.

Hirka A., Csóka Gy. \& Szabóky Cs. 2009: Mit gondolnak az erdei rovarok a klímaváltozásról? In: Lakatos F. \& Kui B. (eds): NYME Erdőmérnöki Kar, Kari Tudományos Konferencia Kiadvány, Sopron, 172-175.

Hlásny T., Mátyás Cs., Seidl R., Kulla L., Merganičova K., Trombik J., et al. 2014: Climate change increases the drought risk in Central European forests: What are the options for adaptation? Forestry Journal (Lesnicki Casopis) 60: 5-18. DOI: 10.2478/forj-2014-0001 
Hubbart J.A., Guyette R. \& Muzika R-M. 2016: More than Drought: Precipitation Variance, Excessive Wetness, Pathogens and the Future of the Western Edge of the Eastern Deciduous Forest. Science of Total Environment 566-567: 463-467. DOI: 10.1016/j.scitotenv.2016.05.108

Janik G., Hirka A., Koltay A., Juhász J. \& Csóka Gy. 2016: 50 év biotikus kárai a magyar bükkösökben. Erdészettudományi Közlemények 6(1): 45-60. DOl: 10.17164/ek.2016.005

Jurc D., Jurc M., Sieber T.N. \& Bojovic S. 2000: Endophytic Cenangium ferruginosum (Ascomycota) as a Reservoir for an Epidemic of Cenangium Dieback in Austrian Pine. Phyton, Special issue: „Root-soil interactions" 40(4): 103-108.

Jurc D. \& Ogris N. 2006: First reported outbreak of charcoal disease caused by Biscogniauxia mediterranea on Turkey oak in Slovenia. Plant Pathology 55: 299. DOI: 10.1111/j.1365-3059.2005.01297.x

Klapwijk M.J., Csóka Gy., Hirka A. \& Björkman Ch. 2013: Forest insects and climate change: long-term trends in herbivore damage. Ecology and Evolution 3(12): 4183-4196. DOI: 10.1002/ece3.717

Kolb T.E., Fettig Ch.J., Ayres M.P., Bentz B.J., Hicke J.A., Mathiasen R., et al. 2016: Observed and anticipated impacts of drought on forest insects and diseases in the United States. Forest Ecology and Management DOI: 10.1016/j.foreco.2016.04.051

Koltay A. 1995: Abiotikus és biotikus tényezők szerepe a feketefenyő állományok pusztulásában. In: Tar K., Berki I. \& Kiss Gy. (eds): Erdő és klíma I. kötet, Noszvaj, 236-240.

Koltay A. 2002: A magyarországi feketefenyő hajtáspusztulás történeti áttekintése. Erdészeti Kutatások 90: 247-254.

Kunca A. \& Leontovic R. 2013: Pines dieback caused by Cenangium ferruginosum Fr. in Slovakia in 2012. Folia Oecologica 40(2): 220-224.

Lakatos F. \& Molnár M. 2009: Mass mortality of beech (Fagus sylvatica) in South-West Hungary. Acta Silvatica \& Lignaria Hungarica 5: 75-82.

Leskó K., Szentkirályi F. \& Kádár F. 1994: Gyapjaslepke (Lymantria dispar L.) populációk fluktuációs mintázatai 1963-1993 közötti időszakban Magyarországon. Erdészeti Kutatások 84: 163-176.

Lindner M., Fitzgerald J. B., Zimmermann N. E., Reyer Ch., Delzon S., van der Maaten E., et al. 2014: Climate change and European forests: What do we know, what are the uncertainties, and what are the implications for forest management? Journal of Environmental Management 146: 69-83. DOI: 10.1016/j.jenvman.2014.07.030

Mares C. \& Mares I. 1994: Climate change-points in the precipitation time series from Romania. In: Atmospheric Physics and Dynamics in the Analysis and Prognosis of Precipitation Fields (Proceedings of the meeting), Rome, 176-180.

Mattson J.W. \& Haack R.A. 1987: The Role of Drought in Outbreaks of Plant-eating Insects. Bioscience 37: 110-118. DOI: 10.2307/1310365

Mátyás Cs., Führer E., Berki I., Csóka Gy., Drüszler Á., Lakatos F., et al. 2010: Erdők a szárazsági határon. Klíma-21 Füzetek 61: 84-97.

Molnár M., Brück-Dyckhoff C., Petercord R. \& Lakatos F. 2010: A zöld karcsúdíszbogár (Agrilus viridis L.) szerepe a bükkösök pusztulásában. Növényvédelem 46(11): 522-528.

Muukonen P., Nevalainen S., Lindgren M. \& Peltoniemi M. 2015: Spatial occurrence of drought-associated damages in Finnish boreal forests: results from forest condition monitoring and GIS analysis. Boreal Environment Research 20: 172-180.

Pálfai I. 2002: Az aszály befolyásoló tényezői és mérőszámai. Vízügyi Közlemények 3: 258-263.

Pernek M., Novak Agbaba S., Lackovic N., Dod N., Lukic I. \& Wirth S. 2012: The role of biotic factors on pine (Pinus spp.) decline in north Dalmatia. Sumarski list 136: 343-354.

Poulos H.M. 2014: Tree mortality from a short-duration freezing event and global-change-type drought in a Southwestern piñon-juniper woodland, USA. PeerJ 2: e404. DOI: 10.7717/peerj.404

Schwantes A.M., Swenson J.J. \& Jackson R.B. 2016: Quantifying drought-induced tree mortality in the open canopy woodlands of central Texas. Remote Sensing of Environment 181: 54-64. DOI: 10.1016/j.rse.2016.03.027 
Sneyers R. 1992: On the use of statistical analysis for the objective determination of climate change. Meteorologische Zeitschrift 1(5): 247-256. DOI: 10.1127/metz/1/1992/247

Suarez M.L., Ghermandi L. \& Kitzberger Th. 2004: Factors predisposing episodic drought-induced tree mortality in Nothofagus - site, climatic sensitivity and growth trends. Journal of Ecology 92: 954-966. DOI: 10.1111/j.1365-2745.2004.00941.x

Szentkirályi F., Leskó K. \& Kádár F. 1994: Jeleznek-e klímaváltozást a fénycsapdás rovargyüjtések? In: Tar K., Berki I. \& Kiss Gy. (eds): Erdő és klíma I. kötet, Noszvaj, 171-177.

Szentkirályi F., Leskó K. \& Kádár F. 1997: Aszályos évek hatása rovarpopulációk hosszú távú fluktuációs mintázatára. In: Tar K. \& Szilágyi K. (eds) 1997: Erdő és Klíma Il. kötet, Sopron, 94-98.

Thomas F.M., Blank R. \& Hartmann G. 2002: Abiotic and biotic factors and their interactions as causes of oak decline in Central Europe. Forest Pathology 32: 277-307. DOI: 10.1046/j.1439-0329.2002.00291.x

Vettraino A.M., Barzanti G.P., Bianco M.C., Ragazzi A., Capretti P., Paoletti E., et al. 2002: Occurrence of Phytophthora species in oak stands in Italy and their association with declining oak trees. Forest Pathology 32: 19-28. DOI: 10.1046/j.1439-0329.2002.00264.x

\section{On-line irodalom}

Szalai S., Auer I., Hiebl J., Milkovich J., Radim T. Stepanek P., et al. 2013: Climate of the Greater Carpathian Region. Final Technical Report. www.carpatclim-eu.org.

Érkezett: 2018. május 1.

Közlésre elfogadva: 2018. május 28. 